\title{
AGRICULTURE OF THE REPUBLIC OF TURKEY (1923-1941) IN THE LIGHT OF YUGOSLAV SOURCES
}

ABSTRACT: Signing the Agreement on the Establishment of Friendly Diplomatic Relations between the Republic of Turkey and the Kingdom of Serbs, Croats, and Slovenes (the Kingdom of Yugoslavia since 1929) on November 28, 1925, provided bases for mutual economic connecting. Concerning the fact that economies of both countries had dominantly agrarian character, they were often rivals to one another in the world markets. Because of that, Yugoslav government aimed at gathering data on the development and modernization of Turkish agriculture by means of its diplomatic representative bodies. In this paper, on the basis of unpublished archival sources, newspapers articles and relevant literature, the following issues will be presented: the state and characteristics of the Turkish agrarian issues during Ataturks's era: the capacity of agricultural production (agriculture, cattle breeding), measures and efforts for its improvement (introducing new kinds and breeds, land-improvement and irrigation projects, the use of modern agro-technical measures, preventing cattle infectious diseases, agrarian reforms, etc.), and the export of agrarian products.

KEYWORDS: agriculture; Republic of Turkey; the Kingdom of Serbs, Croats and Slovenes (Yugoslavia); Ataturk's era; agrarian reform.

virijevicvladan01@gmail.com

This paper was submitted on August $17^{\text {th }}, 2020$ and accepted for publication at the meeting of the Editorial Board held on September $25^{\text {th }}, 2020$. 
The First World War (1914-1918), beside an enormous number of human losses and material demolition, considerably changed the current political world map. On the ruins of the great traditional empires a row of new states arose, among which there were the two Balkan ones - the Kingdom of Serbs, Croats, and Slovenes (SCS) and the Republic of Turkey. The Kingdom of SCS (since1929 renamed as the Kingdom of Yugoslavia) was created by unision of South Slavs on December 1 in 1918, covering about half the territory of the Balkan Peninsula $\left(248.666 \mathrm{~km}^{2}\right)$, it served as a natural connection between Southern, Middle and Western Europe and Asia Minor and Near East. Important land routes were built through it, giving it a specific importance in the international relations. It was one of the key pillars of the Versailles Peace Treaty in the territory of Southeast Europe after the First World War.

Due to the dissagreement on the gross amount of the Ottoman debt, left to the formal and legal successor of the Ottoman Empire, on the occasion of signing of the Sevre Peace Treaty in 1920 and the Lausanne Peace Treaty in 1923, the Kingdom of SCS established official diplomatic relations with the Republic of Turkey on October 28 in 1925, when the Treaty of Peace and Friendship was signed in Ankara (Жупанчић, 2004, p. 10). It was the basis for the future cooperation of the two countries possible, not only in political, but also in economic, cultural, and other aspects. Despite some unsolved issues which burdened bilateral relations between the two countries during the second half of the 1920s-such as repatriation of war prisoners and internees from Turkey, restitution of material goods which were taken from Serbia to the Ottoman Empire during the First World War, mutual protection of the subjects, return of the Turkish subjects displaced from the region that was within the Kingdom of SCS after the Balkan wars and the First World War, etc.-Cooperation between official Ankara and Belgrade recorded an upward trend. Namely, both countries were faced with big political challenges caused by the tendencies of the revisionary countries, such as Bulgaria and Italy, which directed them to mutual closeness and connection, not only in the field of political relations but also in the field of economy and culture. The starting point of it was the Treaty of Peace and Friendship, signed on October 28, 1925 in Ankara (Stojković, 1998, p. 218-219).

With desire to develop the volume of foreign trade business with the Republic of Turkey, ${ }^{2}$ and thus avoid mutual competition in the markets of other countries and realize possible cooperation for the 
joint entry in the opium market, as both Turkey and the Kingdom of SCS were the leaders in the production of high quality raw opium. Official Belgrade systematically collected the data on the economy situation in Turkey - volume of production, prices, financial sector, taxes and customs regulations and tariffs, legislative framework, traffic situation, etc. ${ }^{3}$ Taking that into account, according to the structure and characteristics of their economies, both the Kingdom of SCS and the newly formed Republic of Turkey were listed as 'agricultural countries' in which agricultural production was the most dominant branch of economy providing more than $80 \%$ of population, the Ministry of Foreign Affairs and the Ministry of Trade and Industry paid full attention to the collecting of information on Turkish agriculture - its most prominent branches, volume of production and measures taken for its development, prices and quality of agricultural products, etc. ${ }^{4}$ This data was collected through the activities of diplomatic representatives and the correspondents of the Yugoslav daily newspapers of the Kingdom of SCS in Turkey - obtained by the immediate information in the field, during the talks with representatives of the Turkish state and economy institutions, analysis of the Turkish press and official statistical publications, as well as by certain foreign trade companies which dealt with Turkish tradesmen reports.

2 The first Yugoslav-Turkish agreement on trade was signed on July 3, 1934 and was based on the clause "of the greatest privilege" (Đorđević, 1960, p. 212).

3 Yugoslav-Turkish agreement on the joint placement of opium on the world market was conducted on April 14, 1932 envisaged the establishment of the "Central bureau for opium" with its seat in Istanbul, which would take care of the sale of 77,5\% of Turkish and 22,5\% of Yugoslav opium. "Central bureau" began with work in February 1934 and operated until June 30, 1941. (Archives of Yugoslavia (AY)-411-15-430, Letter of General Consulate of the Kingdom of Yugoslavia in Constantinople to the Embassy of the Kingdom of Yugoslavia in Ankara, 1. VII 1941.; Споразум о извозу опиума, Полиш̄ика, 21. IV 1932, 2; Турско-југословенски централни биро за опијум, Bapgap, 2. I 1934, 1).

4 According to the official data, the Republic of Turkey, in the year 1935, had a population of 16.188 .767 inhabitants, out of which 12.400 .852 were peasants (81.69\% of the total population). Despite proportionate high number of population for which agriculture was basic occupation in the total population of Turkey, law density of population was very low, and there were only 21 inhabitants per a square kilometre. The region with the highest density of the population in Turkey was the Black Sea coast (Karadeniz bölgesi), where the density of the rural population was the highest. Regarding the vilayets, the highest number of agrarian population per a square kilometre lived in Trabzon - 47, then follows Rize - 37, Ordu - 35 and Giresun - 26 (Ibid., 58). 
Before the First World War, the Ottoman Empire was a feudal agricultural country with a large volume of production and significant export capacities, cereals, in particular. Thus, for example, in 1904 it exported $1.350 .000 \mathrm{t}$ of wheat, $700.000 \mathrm{t}$ of rye and $200.000 \mathrm{t}$ of barley. The crops were the main agricultural product and the land they were cultivated on was estimated as 5.750 .000 ha, half of which were wheat sown fields. The total production of crops in 1913 was $408.259 .729 \mathrm{~kg}$, out of which $162.500 .000 \mathrm{~kg}$ went on wheat, partly due to the territory losses, but even more so, to the human losses and immigration of the Greek and Armenian population after the First World War, agriculture of the newly formed Republic of Tukey was facing great difficuties. ${ }^{5}$ Domestic production was not able to meet the needs of the country, so that, in order to provide food for the population, it was necessary to start with imports. According to the data of the Consulate of the Kingdom of SCS in Istanbul, the quantity of cereals in Turkey harvested in 1924 was $3.773 .840 \mathrm{t}$. Out of this quantity, it was necessary to separate $925.000 \mathrm{t}$ for the seed for the following harvest, and $471.000 \mathrm{t}$ for feeding the cattle, so that the population could count on it, but at the same time, in this way, the population was left with $1.340 .000 \mathrm{t}$, of food only, which was not enough. ${ }^{6}$ Wheat sown fileds took up around $85 \%$ of the total arable land. The most important cereals regions were plateaus in Middle Anatolia and fertile plains of Thrace, ${ }^{7}$ which were used for cultivation of wheat, ray, maze, oats and millet. By an intensive enlargment of wheat sown fields, Turkey succeeded not only in meeting the needs for food of its population in the mid 30 s of the last century, but also achieved considerable surpluses which it then exported. ${ }^{8}$ The volume of

The territory of the Republic of Turkey was $770.000 \mathrm{~km}^{2}$ (Ibid., 86).

6 For the needs of Istanbul, as the largest consumer of cereals during 1924, $155.749 \mathrm{t}$ of wheat and $3.850 \mathrm{t}$ of flour were imported from abroad. The largest part of this import came from the United States of America, the Soviet Union, Romania, Australia, Bulgaria and some states of South America. The following year, on Istanbul market appeared wheat from the Kingdom of SCS brought via the Danube, and the Romanian port Braile. Its price was approximately the same as the one in Romania and Bulgaria, but it was lower than the one from the overseas countries. (Archives of Yugoslavia (AY)-411-10-120. The report of the Consulate of the Kingdom of SCS in Istanbul to the Ministry of Foreign Affairs of the Kingdom of SCS, 26. V 1926).

7 The main regions of wheat cultivation were the vilayets such as follows: Konya, Ankara, Eskisehir, Bursa, Manisa, Adana, Kocaeli and Thrache (Ibid., 58). 
wheat production during these years is shown in the following table: ${ }^{9}$

\begin{tabular}{|c|c|c|}
\hline YEAR & QUANTITY (IN TONS) & VALUE (IN LIRAS) \\
\hline 1930 & 7.903 & 577.000 \\
\hline 1931 & 17.101 & 856.000 \\
\hline 1932 & 31.618 & 1.557 .000 \\
\hline 1933 & 26.689 & 1.096 .000 \\
\hline 1934 & 86.828 & 4.081 .000 \\
\hline 1935 & 64.602 & 2.831 .000 \\
\hline
\end{tabular}

In the production of crops, barley was in the second place. It was used mainly for the cattle feeding although considerable quantities of it were exported, as it was appreciated highly for its quality abroad and was used in the production of beer. ${ }^{10}$ As its cultivation required moist soil, it was mostly cultivated in the fields around Adana, Mersin, Manisa, Konya, Eskisehir, Balikesir and in the Gediz valley. Maze was cultivated mainly in the plowing fileds of the Black Sea vilayets, i.e. around Samsun, Rize and Trabzon, in the area of around 200.000 ha. Rye is a crop that was, combined with wheat, mainly used in the domestic flour milling industry. It was cultivated mostly in the vilayets of Kayseri (120.000 quintals), Kirklareli (110.000 quintals) and Edirne (100.000 quintals), in the area covering approximately 360.000 ha. Oats was cultivated to a lesser extent in some plateaus of Anatolia (around $180.000 \mathrm{ha}$ ) and was mostly used as forage, while the arable millet sown fields were mainly in the region of the Sea of Marmara. Its production on the annual level was moving around 200.000 quintals (Михајловић, 1937, p. 60).

Favourable climate conditions in the coastal regions of Turkey offered favourable conditions for the cultivation of vegetables. In the surroundings of Istanbul, cabbage, tomato, spinach, leek, carrot

8 While in the mid of the 20 s of the $20^{\text {th }}$ century Turkey was forced to pay annualy around 10.000.000 liras for the import of wheat, several years later, it gained from its export around 3.000.000 liras (Михајловић, 1937, p. 59).

9 Ibid., 59.

10 The export of barley in the beginning of the 30s of the 20th century had strong fluctuations. In 1930, it was $6.184 \mathrm{t}$, in 1931 it was $91.000 \mathrm{t}$, in $193289.000 \mathrm{t}$, in 1933 it was $49.612 \mathrm{t}$, in $1934148.600 \mathrm{t}$ and, in 1935, it was 52.314 t. (Ibid., p. 60). 
and turnip were cultivated, while garlic and onion were mostly cultivated in the regions along the Black Sea coast. The Black Sea region was also leading in the production of beans. The average annual production of beans was around $17.500 \mathrm{t}$. Out of other legumes, broad bean was cultivated (in the vilayets Canakkale and Izmir around $20.000 \mathrm{t}$ ), chick pea (about $12.500 \mathrm{t}$ ), lentil (oko $8.000 \mathrm{t}$ ) and pea (oko $2.500 \mathrm{t}$ ). Potato was cultivated mainly in the region of Izmir, Afyonkarahisar, Bolu, Konya, Kastamonu, Nigde and Adapazari. Yield of about $25.000 \mathrm{t}$ per year was sufficient for the needs of home market. By modernizing its processing capacities of food industry gradually, Turkey had placed a part of its vegetables for export as canned products, mostly in the markets of Egypt, France and Greece (Михајловић, 1937, р. 62).

An important segment of agriculture was the cultivation of industrial plants - tobacco, cotton, poppy, olive, sugar beet, hemp and sesame. Tobacco was the most important export item of the Turkish agriculture, participating in the total export with more than $20 \%$ of its total value. Cultivated in all parts of the country, it was most found in three regions such as follows: around the Black Sea (Samsun, Bafra, Trabzon, Sinop, Tokat), around Izmir (Denizli, Manisa, Bergama, Odemis, Kasaba, Ayasoluk) and in the region of the Sea of Marmara (Bursa, Izmit, Balikesir, Hendek). Aromatic tobacco from Bafra and Samsun was of the best quality, which because of its thin leaf and aromatic scent was used for mixing with the tobacco from the other provinces, Izmir and Bursa, in particular. Production of tobacco varied from year to year, mostly because of the climate conditions. Thus, in 1927, around $56.000 .000 \mathrm{~kg}$ was produced, in 1930 , it was $47.210 .890 \mathrm{~kg}$, in 1931 , it was $51.111 .051 \mathrm{~kg}$, in 1932, it was 18.040 .212 , while in 1933 , it was $35.367 .126 \mathrm{~kg} .{ }^{11}$ The largest market for its placement was Germany (more than $30 \%$ of the total export of the tobacco), followed by Belgium, Denmark, Czechoslovakia, Italy, Austria, Holland and Poland. In order to maintain the quality intended for export, Turkish "Monopoly administration" forbid tobacco planting in some regions of the country where the conditions were unfavourable for it, and whose weak varieties endangered export rating. While in 1925, 179.751 farming

11 Narodno gospodarstvo - privreda savremene Turske, Obzor, 30. VII 1934, 7.; Производња дувана у Турској и извоз у иностранство, Привреgни ӥреїлеg Кон-

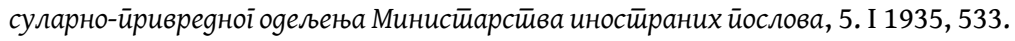


households (663.000 ha) cultivated tobacco, in 1932, their number was reduced to 48.756 (280.215 ha) (Михајловић, 1937, р. 64).

Cotton was cultivated in the regions around Adana, Mersin, Malatya, in the region of Hatay and in the Aegean part of Turkey (vilayets of Izmir, Aydin, Denizli and Manisa). In accordance with climate and geographical characteristics of these regions, three varieties of cotton were cultivated - home "Yerli" (originated from India) and American "Akala" and "Cleveland". Variety "Akala" was sown only in the Aegean zone where it produced the best quality fibres of white colour, whose length was from 35 to $36 \mathrm{~mm}$. Variety "Cleveland", which was not of the same quality as "Akala" (fibre length was from 22 to $26 \mathrm{~mm}$ ), was dominant in the fields of Adana, Mersin, Malatya i Hatay, while the autochtonous variety "Yerli", of the poorest quality of the fibre (yellowish-white colour, its length was from 18 to $20 \mathrm{~mm}$ ) was present in all the regions covering about $50 \%$ of land sown by this industrial plant. ${ }^{12}$ The volume of production of raw cotton depended on the atmospheric conditions, which resulted in such variations. Thus, in rich yield years such as in 1929 and 1931, the yield was about 70.000 t, while in 1928, it failed completely and hardly reached 15.000 t. (Михајловић, 1937, p. 65). Raw cotton was an important item of Turkish export, but parallel with raising of textile industry its export as a raw material was in decline. According to some estimation, at the end of the 20s of the $20^{\text {th }}$ century, the yield of cotton in Turkey, per hectare, was only $75 \%$ in comparison to the average world yield. Production fall of cotton was felt especially in the times of great economic crisis, when a decrease of the total yield from 240.000 quintals in harvesting 1929/30 year to 61.000 quintals in harvesting 1932/33 year was recorded. In this way, the percentage of row cotton participation in the total Turkish export was decreased from $11,4 \%$ in 1930 , to $3,2 \%$ in $1932 .{ }^{13}$

The volume of export of raw cotton for some of the years may be seen from the following table (Михајловић, 1937, p. 66):

12 AY-70-228 The report of Josip Fisher to the union of the textile industries of the Kingdom of Yugoslavia on Yugoslav trade delegation and textile experts journey to Ankara for the purchase of Turkish cotton, 10. VIII 1940.

13 Унапређивање производње памука у Турској, Привреgни йреілеg Консулар-

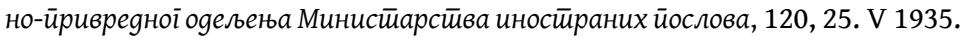




\begin{tabular}{|c|c|c|}
\hline YEAR & QUANTITY (IN TONS) & VALUE (IN LIRAS) \\
\hline 1930 & 32.419 & 16.650 .000 \\
\hline 1931 & 22.745 & 7.400 .000 \\
\hline 1932 & 10.548 & 3.200 .000 \\
\hline 1933 & 5.098 & 1.700 .000 \\
\hline 1934 & 13.279 & 5.200 .000 \\
\hline 1935 & 15.589 & 6.700 .000 \\
\hline
\end{tabular}

Turkey was, in the period between the two World Wars, one of the largest world producers of raw opium, obtained from the poppy fruit. According to some data, its production was about $62 \%$ of the total world quantity of opium at the annual level. Turkish poppy was of the highest quality as it contained as raw material, 12 to $13 \%$ of morphine. The most important areas with plantations of poppy fields were around Izmir, Afyonkarahisar, Amasya, Tokat and between Harput-Malatya. Production of opium depended mostly on the weather conditions in time of seeding and harvesting of poppy. Thus, in 1927, it was only 112 t, $1929-190$ t, $1930-660$ t, $1931-430$ t, 1932 - $123 \mathrm{t}$. Cultivation of poppy was far more profitable than the cultivation of crops, for opium was very much in demand by the world pharmaceutical industry. Istanbul and Izmir were the main exporting ports for the Turkish opium, whose most important customers were France, Germany, England and the USA. ${ }^{14}$ The level of annual export was liable to fluctuation, due to the volume of production and price movements on the markets. In the period from 1925 to 1932 , it was within the range from 225 to $320 \mathrm{t}$, so that it reached $430 \mathrm{t}$ in 1933, and yet in the following year it fell to only $42 \mathrm{t.}^{15}$

14 Narodno gospodarstvo - privreda savremene Turske, Obzor, 30. VII 1934, 7.

15 For the joint appearance on the world market of raw opium, which is eliminating the mutual competition and reducing the impact of cartels of the world producers, Yugoslav and Turkish governments signed an agreement on April 14, 1932 in Ankara on establishing a mixed "Central bureau for opium" with its seat in Istanbul. It began with work on January 1, 1934. - AY-370-12-527, Извештај o турско-југословенском споразуму о извозу опиума, s.a.; Закључен је споразум о продаји опијума између нас и Турске, Време, 2. II 1932, 8.; Споразум о извозу опиума, Полит̄uка, 21. IV 1932, 2.; Турско-југословенски централни биро за опијум, Bapgap, 2. I 1934, 1. 
Sugar beet is an agricultural culture whose cultivation began in Turkey in 1926, when the first factory for its processing was opened in Ushak. ${ }^{16}$ During the following years a rapid growth of sugarbeeet sown fileds was recorded. While, in 1933, it was cultivated on 11.850 ha, it went up in the following year to 60.000 ha covering this cultivation. This enabled Turkey to largerly reduce its dependence on import, so that in comparison to $64.000 \mathrm{t}$, which were imported in 1930, five years later it was only $1.750 \mathrm{t}$ (Михајловић, 1937, p. 72).

Owing to the favourable soil and the climate conditions, the cultivation of olives in the regions of Asia Minor, i.e. in the areas with temperate climate around Aegean (Ayvalik, Edremit and the hinterland of Izmir) and the Sea of Marmara (Mudanya, Gemlik, Erdek, Edincik), has had a long tradition. The top quality olive oil was the one originated from the surroundings of Ayvalik. Turkey was in the fourth place in Europe of both olive and olive oil production behind Spain, Italy and Greece. They were exported mainly to the Soviet Union, Romania, Bulgaria, Syria and Egypt, while volume and value of olive export, in the period from 1930 to 1935, may be seen from the following table: ${ }^{17}$

\begin{tabular}{|c|c|c|}
\hline YEAR & QUANTITY (IN TONS) & VALUE (IN LIRAS) \\
\hline 1930 & 4.741 & 1.884 .000 \\
\hline 1931 & 18.259 & 6.112 .000 \\
\hline 1932 & 2.467 & 773.000 \\
\hline 1933 & 14.181 & 3.442 .000 \\
\hline 1934 & 7.743 & 1.928 \\
\hline 1935 & 6.669 & 1.826 \\
\hline
\end{tabular}

Due to the primitive way of filtration with manual presses and non existence of refinery plants, up to the beginning of the 30s of the 20th century, the quantity and quality of Turkish olive oil was on a low level. That is why it was mostly exported as the raw material to France and Italy, where it was processed in their refineries. However, by the etatization of the Turkish agricultural modern installations for refining, which were erected in the area of Ayvalik

16 After that, sugar rafineries were opened in Alpul, Turhal and Eskisehir (Михајловић, 1937, р. 72.)

17 Ibid., 66. 
and Edremit, the yield from oil export was considerably increased (Михајловић, 1937, р. 66-67).

Sesame is an industrial plant that was cultivated mostly in the plains around the river Meander and in the vilayet of Adana. Its fruit is used for obtaining the oil that can be used as edible, for production of halvah, soap, scents and for the lighting, while the husk can be used for cattle feeding, milking cows, in particular. Sesame oil was an important item of Turkish export - in 1933, when even $3.765 \mathrm{t}$ were exported, in 1934, $1.796 \mathrm{t}$, and in 1935, $688 \mathrm{t}$ (Михајловић, 1937, p. 73).

Beside agriculture, fruit growing and wine growing, raising the cattle also presented an important wide spread agricultural activity, particularly in the central and eastern parts of Anatolia. Dragoslav Mihajlović, an expert in economy and a trade delegate of the Kingdom of Yugoslavia in Turkey, wrote that Anatolia is "a vast pasture sparsed by numerous herds of goats and flock of sheep" adding also that "in terms of cattle raising, Turkey undoubtedly took up one of first places, both in terms of its quality and nobility of the breed" (Михајловић, 1937, p. 80). Great impoverishment of livestock fund during the First World War, due to the sufferings, robbery and epidemies, republican authorities, tried to mitigate by improving ways of raising the livestock. Three large centres for livestock were established in Konya, Karacabey, Sultansuju and Cukurova, as well as in a number of stallion stations and experimental farms for cattle, sheep and goats. They served for improving the domestic breed of cattle and horses by the cross breeding with better quality breed from abroad. In order to make up for the lack of forage, enormous areas which were originally used for grazing of livestock were transformed into artificial meadows from which yields of high quality hey were harvested. These measures contributed to the general increase of livestock number, so that in only two years, from 1923 to 1925 , the number of sheep increased from 9.350 .000 to 12.430 .000 cattle, number of common goat from 5.830 .000 to 6.780 .000 of cattle, number of "Angora" goats from 2.020 .000 to 2.740 .000 of cattle, the cattle from 5.020.000 to 5.370.000, camels from 85.000 to 94.000 , horses from 538.000 to 601.000 , mules from 32.000 to 51.000 of cattle. In this period, the only fall was recorded in buffaloes - from 556.000 to 540.000 (Михајловић, 1937, р. 81).

The most developed branch of livestock, according to the number of cattle, was raising the sheep. The highest percentage of 
sheep consisted of autochtonous breed: "Red Karaman", "Kivircik", "Daglic", "Sakiz", "White Karaman" and "Karayaka". ${ }^{18}$ They were characterized by great resistence to the atmospheric conditions, and they put up "with an ease the harsh conditions of the summers and winters equally" (Михајловић, 1937, p. 81). Sheep "Kiviricik" was appreciated for its high quality milk and very tasty meat, but the quality of its wool was not at the satisfactory level, thus it was mainly used for production of coarse rugs and thick cloth. The breed "Karaman" was also famous for its high quality meat, but even more so, for its tallow and wool. ${ }^{19}$ The "Karayaka" was also highly estimated for its meat, while the "Sakiz", apart from the meat, was also famous for being able to frequently get twins. Areas in which sheep raising was mostly represented were regions around Ankare, Konya, Afyonkarahisar, Balikesir, Manisa, Urfa, Sivas, Izmira, Kars, Kayseri, Eskisehir, Aksaray, Bursa, Kirklareli and Tekirdag.The quality of wool was higher in sheep raised in Thrace than the ones from the Anatolia fields. Production of wool, as row material for textile industry was in rise. Thus, in 1930, $10.000 .000 \mathrm{t}$, was produced while four years later the quantity of wool increased for $70 \%$. The number of sheep reached its maximum in 1927 - 13.630.000, while it fell in 1929 to 10.180 .000 (Михајловић, 1937, p. 81).

Goats were an important category of "flocks". According to the data from 1927, 11.768.259 of cattle was listed in Turkey. The most important breed was so-called Angora goat (around 3.099.520 of them), which had high quality wool, long, shimmering and soft wool, known as "mohair" or "tiftik". ${ }^{20}$ It was highly appreciated, and was used for production of plush and various luxurious fabrics and was mostly exported to the Unites States of America (USA), England, the Soviet Union, Germany and Spain. An average quantity of mohair obtained from one goat was around $1 / 2$ kilogram per annum (Михајловић, 1937, р. 82).

18 Breed "Kiviricik" was raised mostly in the regions of Thrace and west Anatolia, while the breed "karaman" and its varieties were raised in the coastal regions east of the river Sakarya. Breed "Daglic" was commonly found in the regions of Bursa, Balikesir and Canakkale. Sheep "Karayaka" was raised in the Black Sea region, while "Sakiz" was raised in the surroundings of Izmir and Cesme. - Ibid., 80.

19 Breed "Karaman" had around $15 \mathrm{~kg}$ of butterfat in its large tail. AY-334(KPO)-528, Data on trade agreements between Turkey and other countries, on its economy and communications, 12. XII 1934.

20 Narodno gospodarstvo - privreda savremene Turske, Obzor, 30. VII 1934, 7. 
Out of herds, cattle, buffaloes, horses, donkeys and camels were the most raised ones. Horses were used for agricultural work and for the Turkish army needs. Before the Balkan Wars and the First World War, their number was above the number of 130.000 of cattle, but a huge percentage suffered during war activities, so that in the renewal of horsemanship special attention was given. Until 1926, the number of horses grew up to 537.712. As far as the cattle was concerned, the autochtonous breed of law rate of milkiness prevailed and was mostly raised in eastern vilayets. Milk was used for daily nutrition of population and for the production of butter, butter oil and cheese, which were important items of the Turkish export. Out of various kinds of butter and butter oil (fresh, salted, melted or mixed with other fats), butter from the area of Trabzon was especially estimated, while "kasar"and "tulum" cheese, white cheese and cheese in souse were the most wanted in foreign markets (Михајловић, 1937, р. 84).

Rich livestock fund presented, apart from considerable export potential, an important raw base for the intestines and skin processing industry. ${ }^{21}$ In the butcheries of Anatolia, meat and intestines of sheep, goats, cattle and buffaloes were processed. Turkey was known for its production of smoked meat, so-called pastirma and "sujuk"-sausages made from a mixture of beef and mutton and garlic added to it. ${ }^{22}$ Apart from the domestic use, i.e. for nutrition and meat processing industry, intestines were exported into European countries as well as to the USA. In 1930, $293 \mathrm{t}$ was exported, the value of 958.000 liras, in 1934, $273 \mathrm{t}$ (1.074.000 liras), and in $1935,231 \mathrm{t}$ (1.594.000 liras). The best quality was achieved in the butheries of Diyarbekir, Malatya, Konya, Adana, Tarsus and Mersin, where the intestines in diameter of $20-32 \mathrm{~mm}$ in and the length from 25 to $35 \mathrm{~m}$ were processed (Михајловић, 1937, p. 84). Rawhides were processed in the domestic factories and then exported. The average value of annual export of rawhide in the first half of the 20th century was 1.500 .000 liras (Михајловић, 1937, p. 84).

21 Livestock was mostly exported to Syria, Palestine, Greece and the Soviet Union. From 1930 to 1932 it was exported, on average, around 800.000 of livestock, which brought Turkey the income of around 7.800.000 liras. In 1933, the export increased to 896.000, while in 1934, it reached the figure of 1.081 .000 (Михајловић, 1937, p. 84).

22 Smoked meat, especially from the region of Kayseri and "sujuk" was mostly exported to Greece. In 1927, 117 t of "pastirma" worth of 81.151 liras was placed onto its market. - Ibid., 85. 
Raising the poultry was also an important branch of the Turkish agriculture in the period between the two World Wars. According to the information obtained by Dragoslav Mihajlović, around 15.000.000 of poultry were raised in Turkey in mid forties of the $20^{\text {th }}$ century. They were mostly hens -13.725 .580 of them, turkeys around 541.600 of them, geese around -595.960 of them and ducks around -136.860 . Beside 'home breeding' in the village households, rasinig the poultry to a larger extent was most present in the region of Samsun, Kars, Bartin, Trabzon, Ordu and Manisa. Export of eggs is shown in the following table for some of the years: ${ }^{23}$

\begin{tabular}{|c|c|c|}
\hline YEAR & QUANTITY (IN KG) & VALUE (IN LIRAS) \\
\hline 1923 & 5.213 .098 & 1.421 .698 \\
\hline 1924 & 8.661 .395 & 3.726 .516 \\
\hline 1925 & 10.055 .243 & 4.859 .853 \\
\hline 1929 & 11.165 .401 & 6.528 .191 \\
\hline 1930 & 17.870 .292 & 8.324 .512 \\
\hline 1931 & 24.466 .500 & 10.345 .883 \\
\hline 1932 & 24.753 .388 & 8.026 .093 \\
\hline
\end{tabular}

The highest number of customers bying eggs from Turkey were from Spain, Greece, France, Italiy, Germany and Palestine, while the export was carried out via ports in Istanbul, Izmir, Trabzon, Giresun, Ordu, Samsun, Antalia and Mersin, where the exporting contingents were checked by the special expert commissions in order to keep the quality high.

Fruit and wine growing sector was an important segment of Turksih agriculture in the period between the two World Wars, hence a considerable attention was paid to its development. Favourable pedological and climate conditions in the coastal regions of Turkey offered possibilities for cultivation of a number of various sorts of fruit and high quality grapevine. While during the Ottoman Empire, there was only one wine nursery, during the first decade of the republican social system, five more were founded, spreading over the area of 10.000 ha. From their selection viticulturists were given about 826.000 grafts for free. There were seven fruit nurseries in the country out of which up to 1933 the

23 Извоз јаја из Турске, Привреgни ӣреілеg Консуларно-йривреgної оgељења Мини-

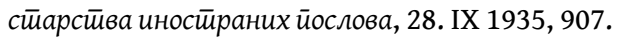


peasants were given 7.421 .350 of various fruit seedlings (Михајловић, 1937, p. 21). The area covered by vineyards during the mid 30s of the $20^{\text {th }}$ century was about 55.000 ha, and their presence, according to the regions, is shown in the following table (Михајловић, 1937, p. 86):

\begin{tabular}{|l|c|}
\hline \multicolumn{1}{|c|}{ AREA } & AREA (IN HECTARES) \\
\hline Izmir, Aydin, Manisa and Denizli & 113.000 \\
\hline Bursa (Hudavendigar) & 87.000 \\
\hline Konya, Burdur, Isparta, Niğde & 42.000 \\
\hline Diyarbakir & 40.000 \\
\hline Elazig and Malatya & 27.000 \\
\hline Maras & 30.000 \\
\hline Amasya and Tokat & 20.000 \\
\hline
\end{tabular}

Grape was, apart from sale in the the home markets, exported as fresh mostly to Syria, the Soviet Union, Greece and Egypt. Out of numerous local sorts by its specific qualities the ones from the surroundings of Konya and Diyarbakir were especially outstanding, for which Dragoslav Mihajlović stressed that their 'taste and smell could not be found in any other country' (Михајловић, 1937, p. 87). Considerable quantities of grapes were exported as dried. The main export port for that type of grape was Izmir, from which around 90\% of total production was exported to the customers in Europe. From 1930 to 1934, the export was in the range of 40-54.000 t, while in 1935, even 76.422 $t$ was exported, for which the Turkish exporters collected around 10.500.000 liras (Михајловић, 1937, p. 88). After the state introduction of monopoly on the production of alcoholic beverages in 1927, the production and export of wine and grape brandy with the addition of anise were considerably improved. The most important wine regions were the Aegean region, Thrace and the region around the Sea of Marmara. In the Aegean region, for the production of wine the most used were the sorts of grapes "Sultana", "Rozaki" and "Muscat" (in the surroundings of Bornova near Izmir), in Thrace, the sort "Papazkarasi" (in the surroundings of Kirklareli) was cultivated, while in the region of the Sea of Marmara the sort "Beyaz Yapincak" (around Gelibolu, Silivri and Tekirdag) ${ }^{24}$ was cultivated. 
Different climate conditions in Turkey were favourable for the cultivation of various kinds of fruit - apples, pears, peaches, apricots, walnuts, plums, chesnuts, hazelnuts, pistachios, figs, oranges, and pomegranate. Vilayets of Ankara and Kastamonu were in particular, famous for the pear quality, Bursa was famous for its tasty apricots, plums and chestnuts, Gaziantep for pistachios, the surroundings of Izmir valley of the rivers Large and Small Menderes) for figs and coastal regions of Hatay for their juicy oranges.

Turkey had a leading position in the world among the growers of hazelnuts. Its hazelnut is greasy and sweet, of much higher quality than the one from Italy and Spain. Huge plantations of hazelnut were spread in the hinterland of the Black Sea coast (regions of Giresun, Trabzon, Ordu) and in the surroundings of Kocaeli, Izmir and Degirmendere. In the mid 30s of the last century, hazelnut trees were covering around 60.000 ha. An average yield in rich yield years was from 1.000 to $1.100 \mathrm{~kg}$ per hectare. If the year of 1929 is exempted, when the harvest failed due to the draught, an annual participation of Turkish hazelnut on the world market was within the range from $36,7 \%$ to $65,5 \%$, thus it represented the most important fruit in the structure of Turkish export. It was exported both with and without husk, mostly to Germany, Italy, France, England, Egypt and the USA (Михајловић, 1937, р. 91).

Areas with fig plantations, cultivated mostly in the Eagean regions of Asia Minor, covered on average around 150.000 ha with 3.500.000 trees. The four sorts of figs dominated such as follows: "suzme", "eleme", "natural" and "hurda". The sort "suzme", characterized by size and white colour was of the best quality. Sort "eleme" had the same colour but was considerably smaller. The "natural" ones were covered by small freckles, and were used for the domestic consummation mainly, while the "hurda" sort was of the poorest quality. However, as it contained a significant percentage of alchohol it was used as an additional ingredient for production of alchoholic drinks and products known as "fig coffee". Almost $90 \%$ of fig harvest was exported both as fresh and dried. In the period of 1930-1934, on average around $26.500 \mathrm{t}$ was exported

24 The best quality Turkish wine was made from "Sultana". It had a clear green-yellow colour and contained $12-13 \%$ of alcohol. By mixing this grape with 'Rozaki" sort, sourish and semi sour wine were produced. Wine from grapes of Thrace contained 11-12 \% of alcohol and was of "fiery red colour" (Ibid., 89). 
per year, while in 1935, a quantity of $37.500 \mathrm{t}$ was achieved (Михајловић, 1937, p. 92).

Although they were not of an equal importance as an export item as hazelnuts, walnuts were also important, because of their quality they were very much in demand on foreign markets, both with or without a husk. ${ }^{25}$ Apart from the fruit, the walnut trees were exported, which was much in demand for the production of gun and elements in the air industry as they were characterized by weight, firmness and were easy for painting, and were also used for obtaining oil (the percentage was around $40-45 \%$ ). The main centres of production of walnuts were the regions of Kastamonu, Bursa, Aydin, Antalia, Diyarbakir, Maras, Sivas, Trabzon, Artvin, Isparta, Giresun, Balikesir and Bolu.

Reorganization of agricultural output on the scientific bases - Within the framework of the reform process of all the segments of Turkish state and its society, government of the Republic of Turkey intended to raise agricultural production on a higher level, so that, it would meet not only the domestic needs, but also gain considerable export potentials, paying special attention to its moderization. Hence, it could be said that the the development of agriculture in Turkey from 1923 presented an obvious example of etatization, trying to eradicate the feudal system in the village and to help the peasant masses without ownership of land, as well as the ones which led a difficult life on small estates, the state conducted a large agrarian reform, which encompassed an area of land of around 800.000 ha (Михајловић, 1937, p. 20).

In order to struggle against livestock contagious diseases, which were widely spread, institutes for bacteriology and serum production were established. At the beginning of the 30 s of the $20^{\text {th }}$ century, around 100.000 animals on average were vaccinated annually. In that way, health state of the livestock was improved considerably. As an example, bovine plague, which in 1922 caused death of around 27.000 of cattle, ten years later, was almost completely eradicated (Михајловић, 1937, р. 84). In the field of plant production, great efforts were undertaken in applying modern agrarian technical tools. Owing to those applications, it was possible to destroy huge swarms of locusts, which came from Syria and Iraq, devastating fields of Turkish farmers. Milions of hectares of land

25 In 1930, around $1.760 \mathrm{t}$ of unshelled and $521 \mathrm{t}$ of shelled walnuts were exported, while in 1935, the export of unshelled walnuts reached $7.057 \mathrm{t}$, and of the shelled ones was only $1.111 \mathrm{t}$ (Михајловић, 1937, p. 93). 
went through the process of deratization, thus being saved from the fatal impact of mice and other field rodents, more than 2.500.000 olive trees were cured, fruit trees and grapevine were protected by the use of various chemical preparations, etc (Михајловић, 1937, р. 21).

As an example of innovation of Turkish agriculture, in the period between the two World Wars, the Yugoslav press often mentioned "Ataturk's estate" in the near vicinity of Ankara. According to the citations of the journalist of Belgrade "Pravda", who paid him a visit in spring in 1938, during 13 years, since the sanation of the terrain which previously consisted of marshes and bulrush, on one side and the arid rocky half desert steppe on the other began, a fascinating change was to be observed. In addition, 3.000.000 of different trees was planted, grapevine gave its fruit three years later, and, in 1930, various sorts of fruit were harvested. The estate became an experimental agricultural property, where selection and breeding of various sorts of crops were carried out, that is their distribution for cultivation in certain geographical regions of Turkey. Moreover, livestock selection station and the largest poultry farm in Turkey were built there. ${ }^{26}$

Selection stations were built in the other parts of the country, too. Thus in Adana and Nazilli they were formed for the cotton quality improvement. ${ }^{27}$ In Eskisehir, Ankara, Adapazari, Adana and Yesilkoy near Istanbul, selection stations were formed in order to improve plant agricultural production in which domestic sorts were crossed with sorts of higher quality from abroad which facilitated climatological-pedological conditions of the cultivation in Turkey ${ }^{28} \mathrm{~A}$ considerable success was achieved in the improvement

26 Орман - угледно имање Кемала Ататурка, Правgа, 11. V 1938, 4.

27 According to some estimations, by the end of the 20 s of the $20^{\text {th }}$ century, yield of cotton in Turkey was per hectare only $75 \%$ of the average yield in the world. The fall in production of cotton was especially felt in the period of great world economic crisis, when the fall of the total yield from 240.000 quintals in the harvesting years of $1929 / 30$ to 61.000 quintals in harvesting 1932/33 was recorded. In that way, the percentage of raw cotton participation in the total Turkish export was reduced from $11,4 \%$, the same as it was in 1930 , to $3,2 \%$ in 1932.- Унапређивање привреде у Турској, Привреgни ӣреілеg Консуларно-ӣривреgної оge-

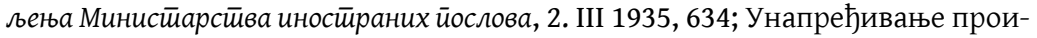
зводње памука у Турској, Привреgни ӣреїлеg Консуларно-ӣривреgної оgељења

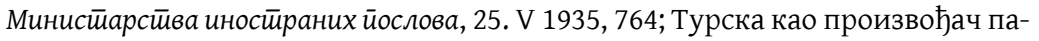
мука, Привреgни ӥреілеg Консуларно-ӣривреgної оgељења Минисӣарсӣва иносйраних йослова, 14. IX 1935, 892. 
of tobacco and opium cultivation. Some attempts for introducing new agricultural sorts which had not been cultivated in Turkey before were made, thus, in 1932, in the vicinity of Maras, the rice was planted. Unknown plants in Turkey such as clover and vetch used as forage were also introduced. A Soviet professor Žukovski was of the opinion that Turkey has conditions for successful cultivation of some subtropic species originated from other continents, such as various plants which were used for the production of expensive oil, raw material for India rubber, bamboo, sugar cane, tea and so on. ${ }^{29}$ In Eskisehir, a project realization of 'Dry farming' was tried, with the aim of propagating American experience in the so-called 'Dry farming', that is, a special way of keeping moisture in the soil by deep plowing. ${ }^{30}$ For better preservation of corn reserves and impact on the market movements, the government erected four silos, each of $4.000 \mathrm{t}$ of capacity, in Ankara, Eskisehir, Konya and Sivas (Михајловић, 1937, p. 21). Considerable attention was paid to irrigation, thus in the vilayet of Konya which was rich with lake water, agricultural areas which were irrigated, rose in number from year to year. Thus, in 1923, 533.915 ha were irrigated, while three years later, irrigation was applied to 1.511.232 ha (Михајловић, 1937, р. 59).

Before 1923, in the whole of Turkey there was only one secondary agricultural school in Bursa. Agricultural experts from abroad, particularly from Germany, were engaged to help modernization of agricultural production, to organize teaching in a number of secondary agricultural schools that republican authorities quickly formed throughout Turkey and to conduct scientific researches on the terrain. ${ }^{31}$ German experts were also professors at the newly established Institute of Agriculture in Ankara, where four faculties were formed: Faculty of Veterinary Medicine, Faculty of Agricul-

28 With such selection methods by which high quality plant sorts from abroad were adapted to the conditions of cultivation in Turkey, a new sort of wheat, called "grain from Metana", was obtained, which had a short period of vegetation and was resistant to diseases (Михајловић, 1937, p. 21). Научна обнова турске пољопривреде, Полийика, 6. XII 1933, 2.

30 Ibid.

31 Famous German botanist, Berlin professor Kurt Krauze investigated structure and characteristics of flora in Turkey in the same way, while the Soviet professor Žukovski after several years of studying "in the field", published a book "Agricultural Turkey", in which he described various agricultural sorts that were cultivated in Turkey. - Научна обнова турске пољопривреде, Полийика, 6. XII 1933, 2. 
ture, Faculty of Natural Sciences and Faculty of Agricultural technology. At the end of the 20s and the beginning of the $30 \mathrm{~s}$ of the $20^{\text {th }}$ century, about a hundred students and professors were sent abroad to study and improve, in order to adopt modern achievements in the agrarian sphere. They were, when they returned home, together with professors from Germany, the first teaching staff in secondary agricultural schools which republican authorities formed throughout Turkey - in Bursa, Izmir, Istanbul and Adana, and were lecturers in agricultural courses organized for teachers and education inspectors throughout the country. In Bursa, Adalia, Erzincan, Adana and Diyarbakir were formed schools for sericulture. ${ }^{32}$ With the aim of educating rural population, the government distributed free scientific publications on modern tendencies in agriculture (books, brochures, propaganda posters) and organized experimental lectures and "agricultural ceremonies" (Михајловић, 1937, p. 20).

The government invested a lot into the modernization of agriculture by introducing modern tools. With the aim of replacing the traditional wooden plough, to the extent as large as possible, by an iron one, it distributed 7.677 and 221 tractor in $1933 .{ }^{33}$ It also tried to distribute free seed and livestock, various financial reliefs for getting modern agricultural machines, instruments and tools, such as tractor, machines for the seed selection, vineyardsprayers and so on. Neglecting until then rooted fatalistic views of the impact of natural conditions on agricultural production, republican authorities, having understood the importance of timely precise weather forecast, formed a Meteorological institute in 1925 in Ankara. Until the beginning of the $30 \mathrm{~s}$ of the $20^{\text {th }}$ century, a meteorological network was built, within which there were, with telegraph line connection, 105 meteorological stations in all parts of the country. ${ }^{34}$ With the aim of strengthening economic power of peasants, the authorities used a number of economic protectionist measures. Thus, for example, it limited the interest rates for loans which farmers took from the private financial institutions, while, on the other side, by mediation of the state "Agrarian bank" (Ziraat banka$s i$ ), it provided loans with more favourable interest rates. Under its supervision, agricultural cooperatives were developed, both in terms of financial loans, and for agricultural products sale, too.

\footnotetext{
Ibid.

33 Ibid.

34 Ibid.
} 
This bank was otherwise a mediator in the agricultural products sale, too, intervening from time to time for the redemption of offered surpluses, in order to maintain price stability (Михајловић, 1937, p. 20, 22). "Agrarian bank" also financed melioration works in the surroundings of Izmir and Adana. It exploited newly gained agricultural areas until it would be able to repay invested fund, and afterwards handed them over to the state ownership.

In an elaborate annual study of the Yugoslav embassy in Ankara on the overall social-economical, political and military safety conditions in Turkey during 1938, it was emphasized that the Turkish agriculture achieved an 'enormous progress' since the introduction of the Republican establishment. However, such progress was seen in an increase of arable land, that is, it was of an extensive nature or, in other words, the growth of the volume of production in the segment of agriculture was not a consequence of considerable appliance of modern agrarian technical measures but the growth of the sown areas. Thus, in 1937, the area of arable, sown parcel was 3.500.000 ha, so that in the following year, it could be increased for the new 1.000.000 ha. However, yields of Turkish agriculture were still under the Yugoslav and European average - in 1938, in Turkey from the area of one hectare, $825 \mathrm{~kg}$ of wheat was on average harvested, while in the Kingdom of Yugoslavia an average harvest was $1.100 \mathrm{~kg}$. Barley yield in Turkey was harvested $950 \mathrm{~kg}$ per hektare, while Yugoslav average was $1.350 \mathrm{~kg}$. Similar relation was noticed in the case of potato yield - while in Yugoslavia, $5.700 \mathrm{~kg}$ per hectare was harvested, in Turkey it hardly reached $3.000 \mathrm{~kg}$. Even more drastic difference was observed in the rice yield - while in Italy, per one hectare $4.950 \mathrm{~kg}$ on average was harvested, Turkish producers of rice harvested only $1.860 \mathrm{~kg} .{ }^{35}$

- Archives of Yugoslavia:

Legations of the Kingdom of Yugoslavia in Turkey - Konstantinople, Ankara (1890-1945) - 370.

General consulate of the Kingdom of Yugoslavia in Constantinople (19061945) - 411.

35 Archives of Yugoslavia (AY) - 370-21-24, Study of the Embassy of the Kingdom of Yugoslavia in Ankara on social-economic, political and military-safety conditions in Turkey in 1938, 27. III 1939. 


\section{PUBLISH SOURCES}

Stojković, M. (1998). Balkanski ugovorni odnosi 1876-1996, tom II (1919-1945). Beograd: Službeni list SRJ.

\section{PRESS}

Obzor - Zagreb

Полийика - Beograd

Правgа - Beograd

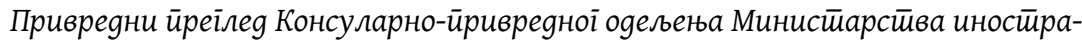
них йослова - Beograd

Bapgap - Skoplje

Bpeme-Beograd

REFERENCES Đorđević, B. (1960). Pregled ugovorne trgovinske politike od osnivanja države Srba, Hrvata i Slovenaca do rata 1941. godine (sa dopunom Dr. Save Obradovića o plurilateralnim sporazumima Jugoslavije 1934-1941. i predgovorom akademika Mija Mirkovića). Zagreb: JAZU.

Михајловић, Д. (1937). Привреда савремене Турске. Београд: Балкански институт.

\section{ВЛАДАН А. ВИРИЈЕВИТ}

УНИВЕРЗИТЕТ У ПРИШТИНИ СА ПРИВРЕМЕНИМ СЕДИШТЕМ

У КОСОВСКОЈ МИТРОВИЦИ, ФИЛОЗОФСКИ ФАКУЛТЕТ

КАТЕДРА ЗА ИСТОРИЈУ

САЖЕТАК

$$
\text { ПОљОПРИВРЕДА РЕПУБЛИКЕ ТУРСКЕ (1923-1941) }
$$

У СВЕТЛУ ЈУГОСЛОВЕНСКИХ ИЗВОРА

У контексту свеобухватних друштвених промена које су захватиле турску државу и друштво након проглашења републиканског државног уређења, нове власти су са циљем модернизације и вестернизације пуно пажње посветиле привредним токовима. У хронолошким оквирима овог рада Турска је, као и Краљевина Срба, Хрвата и Словенаца (Југославија), представљала својеврсни „аграрни океан“, при чему је пољопривреда чинила преовлађујуће занимање становништва, а аграрни продукти представљали су окосницу турског извоза. Упркос изузетној 
ठлискости на политичком плану и интензивним ठилатералним односима, на спољнотрговинском нивоу, тј. светском тржишту аграрних производа, југословенска монархија и турска република су, упркос извесних заједничких активности у пласману опијума, једна другу доживљавале као непосредног конкурента. Стога су југословенски државни органи надлежни за спољну трговину с великом пажњом пратили кретања у сфери турске пољопривредне производње, како би захваљујући тим сазнањима успешније креирали експорт југословенских пољопривредних производа, односно избегавали могућност турске конкуренције. У извештајима југословенских дипломатских представништава у Републици Турској, специјалиста за привреду и спољну трговину и новинским написима приказиване су основне карактеристике турске пољопривредне производње и њеног експорта. У њима су се уочавале интензивне модернизацијске промене турског аграра инициране с највишег државног нивоа које су резултирале увођењем нових сорти и пасмина, те применом савремених агротехничких мера и уздизањем пољопривредне производње на квалитативном и квантитативном нивоу, што је последично резултирало увећањем експорта.

КључнЕ Рєчи: пољопривреда; Република Турска; Краљевина Срба, Хрвата и Словенаца (Југославија); Ататурково доба; аграрна реформа.

Овај чланак је објављен и дистрибуира се под лиценцом Creative Commons Ауторство-Некомерцијално Међународна 4.0 (CC BY-NC 4.0 |

https://creativecommons.org/licenses/by-nc/4.0/).

This paper is published and distributed under the terms and conditions of the Creative Commons Attribution-NonCommercial International 4.0 licence (CC BY-NC 4.0 | https://creativecommons.org/licenses/by-nc/4.0/). 